\title{
Discussion of Design and Experiential Marketing in Ming-Show Pottery Cultural Creative Product
}

\author{
I-Yu Chen ${ }^{1}$, Chi-Hsiung Chen ${ }^{2}$, and Cheng-Hsui Chen ${ }^{1}$ \\ ${ }^{1}$ National Yunlin University of Science and Technology Graduate School of Business \\ Administration, No.123, University Road, Section 3, Douliu, Yunlin 64002, Taiwan \\ g9922706@yuntech.edu.tw, chencs@yuntech.edu.tw \\ ${ }^{2}$ National Yunlin University of Science and Technology Graduate School of \\ Creative Design, No.123, University Road, Section 3, Douliu, Yunlin 64002, Taiwan \\ chenchs@yuntech.edu.tw
}

\begin{abstract}
In the present day, the government of Taiwan is tiring to promote the policy of Cultural Creative Industries (TCCI), as well as to industrialize the cultural products with creation; thus, marketing is the major factor in industrial operation; furthermore, the exterior environment, competition between the same industries, promotion and sales of the distribution and the interior creative ability become the important points for the industry. This study was focused on the case study which discussed about the interior and exterior marketing strategy analysis of Ming-Show Pottery. The relevant information was obtained from domestic and foreign literatures, which also included interviews to understand the actual operating situation deeper for the industry by interview; meanwhile the SWOT analysis was also adopted in this study to understand the poisoning, external opportunities and threats and the internal advantages and disadvantages of target markets. The study results are obtained as follow (1) The model of Experiential Strategy consists of five factors: Sense, Emotions, Thoughts, Action and Connection; so that the customer will interest in the product and culture by stimulating those five factors; ;(2) The applied strategies in the future which including brand marketing, selling spots expansion, experiential marketing ways and different industrial collaboration were made via SWOT analysis as the foundational references to the industry; and (3) Establishing the model of experiential marketing strategy applications can improve the competitive ability of marketing promotion for the industry in terms of interactional marketing.
\end{abstract}

Keywords: Ming-Show Pottery, Lazurite, Cultural Creation, Marketing Strategy, SWOT.

\section{Introduction: The Background and Motivation of the Study}

As the progress of technology and the convenience of information transmission, the cultural industry of Taiwan has turned to the TCCI in present by the promotion of government. Culture means life of past, and the industry can be more creative if it can combine with innovation. As a result, how to promote cultural creative products to more consumers and allow them to get involved into consumptive experience besides to 
preserve and continue the culture of the industry will be the main point. "Cultural Industries" refers to contents of creation, production and the business, and the essence of it is the intangible assets and with cultural concept, and is usually protected by the intellectual property rights and presented by the forms of product and service (UNESCO, 2008). Therefore, the industry those take creative style as the core value will have highest added value by design; it combines not only culture, creation and uniqueness of product, but bring the infinite opportunities and growing space for economy.

As the reasons above, this study focused on the case study which discussed about the interior and exterior marketing strategy analysis of Ming-Show Pottery, as well as to introduce the concept of "experiential marketing". The relevant information was obtained from domestic and foreign literatures, which also included interviews to understand the actual operating situation deeper for the industry by field study. The research purposes can be inducted as following four points:

1. The foundation of the study theory was through the discussion of literatures to understand the implications of experiential marketing.

2. To understand the design and develop process and the general operating situation of Ming-Show Pottery by field study.

3. To consider the problems that the industry may face and the solvents it may adopt by SWOT analysis in terms of design marketing.

4. Finally, to construct the experiential marketing strategies for the industry to be the reference in their future operation.

\section{Literature Review}

\subsection{The Discussion of Experiential Marketing}

What is Experiential Marketing? Experience is not only defined as the product's concept or the evolution after purchased by customer, but all activities that could influence customer's purchasing decision can be called experience. In brief, experience refers to the value of consciousness, emotion, cognition, behavior and connection to replace the value of product's functions. Such as, the ridding probation project of automobile industry which allow customer to replace the value of the product itself with the trial experience. Therefore, Amould et al (2002) had divided experience into four stages:

1. The Pre-consumption Experience: Including search, plan, dream, predict and guess to the experience.

2. The Purchase Experience: Derive from the interaction between selection, payment, packaging, service and environment.

3. The Core Consumption Experience: Including consciousness, sense of repletion, satisfaction or discontent, discomfort or comfort and transformation.

4. The Remembered Consumption Experience and the Nostalgia Experience: It can help the photograph to be alive and allow people to feel old experience through storytelling, and discuss about past with friends; it can be helpful to memory classification as well.

Experiential Marketing: The experience marketing refers to a product or service, which selects some methods to provide the sensational, creative or emotional 
experience to create extra experience value for the consumer. Therefore, Schmitt (1999) pointed out the "experience medium" includes communication, identification, product, brand establishment, environment, websites, human and so on. These experience media may create sense, emotion, thinking, action and connection. Customer will stimulate their needs by these factors to obtain the preference for product. Such as in automobile industry, aviation industry or the food industry enable the customer to have tries by themselves to urge customer interested in the product then increase the consumptive desires.

Fig. 1 Strategy experiential mold are composed of five factors- Sense, Emotion, Thinking, Action and Connection.

1. Sense Marketing: Composed of vision, hearing, taste, smell and touch to stimulate customer's sense experience and increase extra value to product. For example: The decoration of Ming-Show Pottery's store can attract the customer's visual feeling by the aborigine's totems, pictures or the traditional clothing.

2. Emotion Marketing: Emphasizes on customer's interior emotion, and creates connection with product by their own experience. Such as customer's consumptive behavior created by having the emotion with the product.

3. Thinking Marketing: It can initiate customer to create the experience of reorganization and problems solving via curious, interest so as to excite creative thinking from customers.

4. Action Marketing: It is used to create the customer experience which relates to the behavior mode and life style, including the experience occurred by interacting with others to change the consumptive habits.

5. Connection Marketing: It consists of sense, emotion, thinking and action marketing, and the major point in connection marketing is the right specific group and choice with demand; moreover, it can bring more experiences to customer by those factors. Thus, Ming-Show Pottery can stimulate experience on the five senses through their products to customers so as to make them interest in cultural cognition and comprehension to the products.

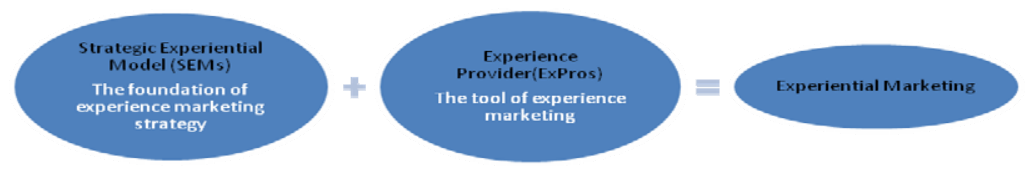

Fig. 1. The Model of Experiential Marketing (Schmitt, 1999)

\subsection{Ming-Show Pottery}

Colored glaze bead is the symbol of Paiwan culture, it also stands for the symbol of human's specific ideas; each colored glaze bead has different myth legend and denomination by the different color, pattern/motif. Ming-Show Pottery adopts the pith of the culture and applies on the creation and design to create cultural products which are different from in traditional aboriginal culture'. The products combine with other materials so as to make them to have more creation and customization on design. The brief introduction about the entrepreneur as shown in Table 1, and the Table 2 is the product design of colored glaze bead. 
Table 1. The introduction of Ming-Show Pottery

\begin{tabular}{|l|l|}
\hline Entrepreneur & Ming-Show Pottery \\
\hline Set up time & June,15 $5^{\text {th }}$ 2003 \\
\hline Person in charge & Ming- Zhi Li, Xiu-Uha Wu \\
\hline Telephone & $07-6101933$ \\
\hline Address & $\begin{array}{l}82647 \text { No.200, Lane 263, Jhanbao Rd., Zihguan Dist., Kaohsiung City } \\
82647, \text { Taiwan (R.O.C.) }\end{array}$ \\
\hline Brief introduction & $\begin{array}{l}\text { Ming-Show Pottery was named by the founder's name by the meaning of } \\
\text { crating the culture art career together; they specialized in the handicraft } \\
\text { article of aboriginal colored glaze bead and aboriginal related works. The } \\
\text { products of Ming-Show Pottery have been selected as gifts for foreign guests } \\
\text { by the chair man of Tourism Bureau unexpectedly, and thus being popular in } \\
\text { Korea and Japan. The shop is looking forward to being one of cultural } \\
\text { industries to be more exquisitely and art at present. }\end{array}$ \\
\hline Product development & hanging ornament, jewelry, necklace, hand lace, hairpin, hat...etc. \\
\hline
\end{tabular}

Table 2. The characteristic of cultural creative product (organized by the author)

\begin{tabular}{|c|c|c|}
\hline Product type & Product picture & Product feature/ cultural story \\
\hline Necklace & & $\begin{array}{l}\text { "Bead of Dexterity" } \\
\text { Legend: Papilio is famous by it's straighten fly. It } \\
\text { symbolizes a person who works agile and quick in } \\
\text { the movement so it's a suitable gift for an athlete and } \\
\text { pragmatic worker. }\end{array}$ \\
\hline Hand lace & & $\begin{array}{l}\text { "Bead of Brave" } \\
\text { Legend: The person who has the outstanding } \\
\text { distribution to the tribe or heroic performance in the } \\
\text { battlefield can be given the bead. It can help to } \\
\text { increase intelligent and brave. It symbolizes } \\
\text { protection and security, advance bravely and } \\
\text { extraordinary achievement. }\end{array}$ \\
\hline Hairpin & & $\begin{array}{l}\text { "Bead of Woman Weaver" } \\
\text { (also called bead of virginity) } \\
\text { Legend: The old will donate the Palic necklace or } \\
\text { hairpin to the daughter who is waiting to be married } \\
\text { and it is suitable to be used in nubile age. It } \\
\text { symbolizes the treasure, chastity and high technique, } \\
\text { and is suitable to be worn by damsel and artist. }\end{array}$ \\
\hline $\begin{array}{l}\text { Hanging } \\
\text { ornament }\end{array}$ & & $\begin{array}{l}\ulcorner\text { Bead of Sun }\lrcorner \\
\text { Legend: It is said that there was a chieftain who } \\
\text { always wears a sad face due to the hard transmission } \\
\text { of information in the secluded mountain where he } \\
\text { lives; then the celestial old man showed up who was } \\
\text { willing to be the representative for the chieftain to } \\
\text { make contract with the sun, and the sun promised } \\
\text { him to call his people by the light. It symbolizes } \\
\text { eternal pledge and unchangeable promise. }\end{array}$ \\
\hline $\begin{array}{l}\text { Compound } \\
\text { material }\end{array}$ & & $\begin{array}{l}\ulcorner\text { Bead of the Pottery Pot }\lrcorner \\
\text { Legend: The pottery pot in Paiwan is considered to } \\
\text { noble's heirloom. And the boar tooth bracelet is } \\
\text { considered as the man who has the heroic deeds in } \\
\text { killing the wild boar, which is also distributed to the } \\
\text { society. It consist of two materials to create another } \\
\text { meaning for cultural product, and was designated to } \\
\text { be the souvenirs in the } 2009 \text { World Games in } \\
\text { Kaohsiung }\end{array}$ \\
\hline
\end{tabular}



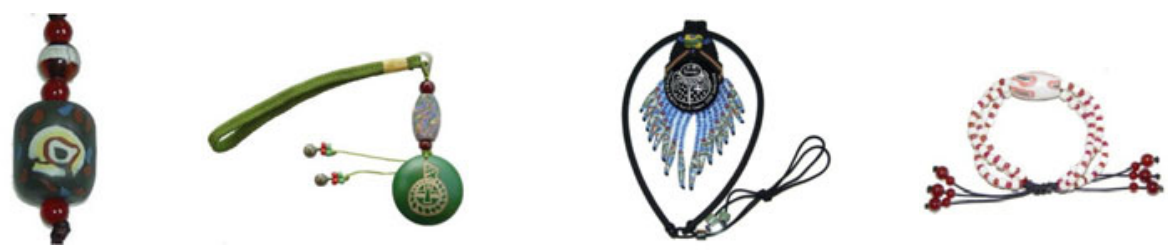

Fig. 2. Products of colored glaze bead

\subsection{The Relationship between Product and Experiential Marketing}

There are many industries have connected products to experiential marketing in present day, such as the Starbucks which provides a temporary conference room, workroom, reading room with pictures and music to create certain kinds of phenomenon. Furthermore, IKEA sales the product by the form of family market to build the situation of living room, kitchen, and bedroom which allow customers to experience the phenomenon personally. In meanwhile, it will increase its exposure rate via the experiential media to promote the public relations so as to update the product value; thus, the experiential value can be improved by the explanation and promotion of the business owners. Therefore, the relations between products and experiential marketing can be strengthen by allowing consumers to experience the making process of colored glaze bead to produce their unique product by themselves. Moreover, it can use aboriginal situations, storytelling by the business owner and network to attract general customers to improve the relations as well.

\section{Methodology and Procedures}

\subsection{Research Object}

This study took Ming-Show Pottery as the object.

\subsection{Methodology}

1. SWOT analysis: It consists of advantage, disadvantage, opportunity and threat; the basis profit can be found by using advantages and opportunities to improve the disadvantages and threats. This study analyzes the advantages and opportunities of Ming-Show Pottery then to improve he disadvantage and threat by the establishment of the experiential marketing strategy.

2. Sample analysis: Analyzes the information from collection literatures, which can be the pictures, literatures, data or concrete object as well as to integrate the factors from the samples. This study had collected the first information via interviewing the Ming-Show Pottery to analyze the cultural products so as to understand the implications of product creation.

3. Case study: It can be adapted to progress in-depth study in order to determine the factors that can result in certain states or behaviors from individuals groups or institutions, or the relations between various factors (Wun-ko Wang, 2002). This study focused on cultural products of Ming-Show Pottery case to draw up the experiential marketing strategies which can be the operating reference for the business owner. 


\subsection{Research Procedures}

This study can be divided into three steps, first step was the establishment of study object and purpose, then discussed the literature review to establish the base for the study theory; step two was to carry on the work of interview and record on Dec., 2010 by field study; after the analysis of the interview records, the last step was to make experiential marketing strategy to Ming-Show Pottery via marketing strategy manner.

\section{Results and Discussion}

\subsection{The Analysis of Cultural Creative Product}

According to the Ming- Show's actual development of the culture creative product, the classification of the products can be divided into five types which are the necklace, bracelet, anklet, hairpin, hanging ornament, key chain, compound materials design via the field investigation and interview to the founder; the attribute of the products is shown as table 2 :

\subsection{Investigation and Analysis of Industrial Operation Interview}

This study had adopted in-depth field study to understand the details of the present operational situation to the business owners in January 2011; the subjects of the interview were divided into four parts: (1) Upstream- Creative research and development (2) Midstream- production and process (3) Downstream- selling situation and (4) Comprehensive discussion. The relevant subjects were detailed divided into other factors for discussion so as to record and establish the firsthand data as the basis for analyze. The analyze process of the information arrangement is shown as Table 3 .

\subsection{SWOT Analysis}

This study has integrated the information about the present developing situation of Ming-Show Pottery, and has analyzed the design features of cultural product as well as to record the local field study to organize the factors of advantages, disadvantages, opportunities and threats for the shop's operation as shown in Table 4.

In Table 4 we can know how to hold the opportunities by the advantages when facing the future strategies of the industrial development; excepting to enhance the local cultural image and to promote the fame and competitive ability for the industry, developing local cultural products can bring to the development of business opportunities and promotion of cultural features so as to attract more visitors. Moreover, the disadvantages and threats can be improved by ways of different industrial cooperation to work with other art and cultural business owners, as well as to improve the design and develop ability of cultural products, enhance marketing strategy, expanding selling spots; the methods above are the essential factors to the industry in future operation. 
Table 3. The analysis of industrial operation general situation (compiled by the author)

\begin{tabular}{|c|c|c|}
\hline \multirow{5}{*}{ 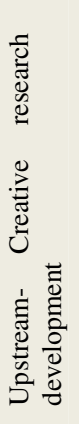 } & Creative elements & $\begin{array}{l}\text { (1) needs of cultural transition(2) needs of life( } 3 \text { ) needs of } \\
\text { educational meaning( } 4 \text { )needs of market (5)different material } \\
\text { combination (6) infinite extending development of Lazurite Art } \\
\text { works (7) cultural combination and development of aboriginal } \\
\text { populations }\end{array}$ \\
\hline & Creation source & $\begin{array}{l}\text { (1) to develop and produce a sample product according to the } \\
\text { needs of market (2) tailor-make for customer's need ( } 3 \text { ) old } \\
\text { products re-seek for new materials (4) remix traditional and } \\
\text { modern design style (5) stories and legends of aboriginal culture }\end{array}$ \\
\hline & Creation predicament & $\begin{array}{l}\text { (1) fund (2) technological upgrading (3) human resource } \\
\text { management (4)advertisement and marketing channel (5) display } \\
\text { channel (6) recognition to product from market }\end{array}$ \\
\hline & Production method & To make with extra care by handmade \\
\hline & $\begin{array}{l}\text { Cultural features of the } \\
\text { industry }\end{array}$ & $\begin{array}{l}\text { To spread and inherit aboriginal culture of Paiwan so as to } \\
\text { expend the new market for cultural creative industries. }\end{array}$ \\
\hline \multirow{5}{*}{ 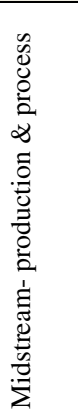 } & $\begin{array}{l}\text { Applied material of } \\
\text { product }\end{array}$ & $\begin{array}{l}\text { (1) pottery (2) wood (3) ore (4) fabric (5) rock (6) silver (7) agate } \\
\text { (8) dzi beads (9) turquoise (10) soapberry (11) crystal (12) animal } \\
\text { teeth }\end{array}$ \\
\hline & Product variety & $\begin{array}{l}\text { Relevant Lazurite necklace, bracelet, anklet, chatelaine, hair pin, } \\
\text { clothing and so on. }\end{array}$ \\
\hline & Creation series & $\begin{array}{l}\text { (1) pearl of sun (2) pearl of noble (3) pearl of woman weaver (4) } \\
\text { pearl of brave warrior (5) pearl of land (6) pearl of peacock (7) } \\
\text { pearl of tactician (8) butterfly series }\end{array}$ \\
\hline & Production mechanism & All products are produced and developed by the shop itself. \\
\hline & Production predicament & $\begin{array}{l}\text { (1) fund research and development (2) mass production for } \\
\text { customization (3) market channel (4) recognition to product from } \\
\text { market }\end{array}$ \\
\hline \multirow{4}{*}{ 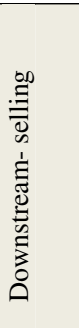 } & $\begin{array}{l}\text { General situation of } \\
\text { market }\end{array}$ & $\begin{array}{l}\text { Buyers: are divided into official and civil individual. The market } \\
\text { depends on official, governmental and general public buyers in } \\
\text { present. }\end{array}$ \\
\hline & Major selling market & $\begin{array}{l}\text { (1) government gift (2) cultural market(3) creative market (4) } \\
\text { teaching market (5) activity market }\end{array}$ \\
\hline & $\begin{array}{l}\text { Present marketing } \\
\text { strategies }\end{array}$ & $\begin{array}{l}\text { (1) stands of creative market (2) street artists(3) Internet selling } \\
\text { (4) introduced by friends }\end{array}$ \\
\hline & $\begin{array}{l}\text { Future marketing } \\
\text { strategies }\end{array}$ & $\begin{array}{l}\text { (1) industry-university cooperative research project (2) attending } \\
\text { national contests to increase fame (3) to be selected in the } \\
\text { certification of craft house }\end{array}$ \\
\hline \multirow{3}{*}{ 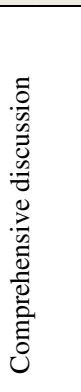 } & Product plan & $\begin{array}{l}\text { The technologic instruction of product package design, marketing } \\
\text { design and management, science and technologic fabrication or } \\
\text { craft design can make art works into products, as well as to apply } \\
\text { the aboriginal cultural features to the Lazurite works in order to } \\
\text { design unique products by industry-university cooperative } \\
\text { research project. }\end{array}$ \\
\hline & Product production plan & $\begin{array}{l}\text { Introducing design esthetics and cultural design implications, as } \\
\text { well as to make the product to be sophisticate, artistic, living and } \\
\text { characteristic style design. Moreover, mass-production can } \\
\text { improve the output value for the workroom. }\end{array}$ \\
\hline & Future development plan & $\begin{array}{l}\text { Establishing Paiwan aboriginal culture museum to attract more } \\
\text { visitors and to increase operating income. }\end{array}$ \\
\hline
\end{tabular}


Table 4. SWOT analysis of Ming-Show Pottery

\begin{tabular}{|c|c|}
\hline Strength & Weakness \\
\hline $\begin{array}{l}\text { 1. It has abundant aboriginal cultural stories and } \\
\text { legends. } \\
\text { 2. The selling spots is in the prosperous city where } \\
\text { can attract more people to notice their products. } \\
\text { 3. The products combine with and apply other } \\
\text { natural materials to create diverse product } \\
\text { values. } \\
\text { 4. The products can be designed and produced at } \\
\text { home. } \\
\text { 5. Cultural products have their own brands; this can } \\
\text { helps to be easy recognized and different with } \\
\text { others. } \\
\text { 6. It has own designers and selling stuffs to lower } \\
\text { human resource cost. } \\
\text { 7. The shop can be reserved for visiting which can } \\
\text { help to reach the purpose of experiential } \\
\text { marketing. }\end{array}$ & $\begin{array}{l}\text { 1. Lazurite has to be produced by mass human } \\
\text { resource; it's hard by mechanical mass } \\
\text { production. } \\
\text { 2. The culture of aborigine is hard to be } \\
\text { accepted by Han people; therefore many } \\
\text { consumers are not familiar with the features } \\
\text { of the industry. } \\
\text { 3. It lacks of marketing channels, so it's hard } \\
\text { to expend the scale of the industry. } \\
\text { 4. It lacks of professional managers and } \\
\text { marketing staffs. } \\
\text { 5. The abilities of innovative develop and } \\
\text { design has to be improved. } \\
\text { 6. It lacks of well package design. } \\
\text { 7. It has greater cost for production. }\end{array}$ \\
\hline Opportunity & Threat \\
\hline $\begin{array}{l}\text { 1. It can join the industry - university cooperative } \\
\text { research project to improve the industrial } \\
\text { competitive ability. } \\
\text { 2. To go deep into the basic levels of population to } \\
\text { promote the Lazurite culture through activities. } \\
\text { 3. To accept the assist policies which help to } \\
\text { promote art and cultural industries by } \\
\text { government? } \\
\text { 4. To work with local governments so as to } \\
\text { develop the gifts for the local regions. } \\
\text { 5. To contact with mediums more actively so as to } \\
\text { increase the measures of placement marketing. } \\
\text { 6. To attend national competitions or apply to the } \\
\text { fine works' and craft house's certifications so as } \\
\text { to increase the fame for the industry. } \\
\text { 7. The attribute of the industry can be listed as the } \\
\text { sightseeing factory, or to build the Paiwan } \\
\text { aboriginal cultural museum so as to expand the } \\
\text { strategy of experiential marketing to attract more } \\
\text { visitors and incomes. }\end{array}$ & $\begin{array}{l}\text { 1. There are more same business operators } \\
\text { with the same industrial attribute in the } \\
\text { market; as a result the environment of the } \\
\text { industry has great competition. } \\
\text { 2. The business owners of art and cultural } \\
\text { industry can corporate with cross-industrial } \\
\text { union mechanism to increase the added } \\
\text { value. } \\
\text { 3. The business owners of art and cultural } \\
\text { industry have various marketing platform, } \\
\text { and the workroom of the industry combines } \\
\text { with experiential marketing strategy to } \\
\text { promote and increase output value and } \\
\text { income. } \\
\text { 4. The product of the same attribute have lower } \\
\text { unit price in general due to the mass } \\
\text { production and development. } \\
\text { 5. The beneficial result can be increased due to } \\
\text { the speed of mass production. } \\
\text { 6. The cultural products of art and cultural } \\
\text { industry can be customization in mass } \\
\text { production. }\end{array}$ \\
\hline
\end{tabular}

\subsection{Ming-Show Pottery-Experiential Marketing Strategy}

Ming-Show Pottery shows that the shop can bring customers five senses experience by crating experiential phenomena; it also use experiential media to allow consumers in-depth understand the cultural story which introduces the implication of Lazurite. Furthermore, the shop allows consumers to make their own Lazurite by themselves so as to increase their interests on the products and to promote the selling rate. Table 5 is the experiential marketing strategy made for Ming-Show Pottery by this study; it applied the strategic experience module and five senses elements as well as to combine aboriginal cultural factors to show the experiential marketing process. 
Table 5. Experiential marketing strategy of Ming-Show Pottery

\begin{tabular}{|l|l|l|l|}
\hline $\begin{array}{l}\text { Strategy } \\
\text { experience } \\
\text { module }\end{array}$ & $\begin{array}{l}\text { Five } \\
\text { senses }\end{array}$ & $\begin{array}{l}\text { Applying } \\
\text { factors }\end{array}$ & $\begin{array}{l}\text { Experiential } \\
\text { process }\end{array}$ \\
\hline $\begin{array}{l}\text { Sensational } \\
\text { marketing }\end{array}$ & $\begin{array}{l}\text { vision } \\
\text { hearing } \\
\text { touch }\end{array}$ & $\begin{array}{l}\text { Aboriginal totem and } \\
\text { symbol aboriginal music } \\
\text { experiential DIY of } \\
\text { Lazurite }\end{array}$ & $\begin{array}{l}\text { Customers can hear the aboriginal music, and } \\
\text { appreciate the phenomenon which is created by } \\
\text { aboriginal cultural graphics and decorations when } \\
\text { they step into the store; moreover, they can } \\
\text { experience Lazurite DIY by themselves as well. }\end{array}$ \\
\hline $\begin{array}{l}\text { Emotional } \\
\text { marketing }\end{array}$ & $\begin{array}{l}\text { vision } \\
\text { hearing }\end{array}$ & $\begin{array}{l}\text { Cultural and story } \\
\text { film narration, } \\
\text { staff explanation, } \\
\text { film introduction }\end{array}$ & $\begin{array}{l}\text { Staff explanation or film narration can help } \\
\text { customers to develop emotion and recognition in } \\
\text { Lazurite culture as well as to understand the } \\
\text { implication of aboriginal culture. }\end{array}$ \\
\hline $\begin{array}{l}\text { Thinking } \\
\text { marketing }\end{array}$ & $\begin{array}{l}\text { vision } \\
\text { hearing } \\
\text { touch }\end{array}$ & $\begin{array}{l}\text { Film introduction } \\
\text { aboriginal music } \\
\text { Lazurite DIY experience }\end{array}$ & $\begin{array}{l}\text { Allowing customers to produce curiosity and } \\
\text { provide more creative ideas through the music } \\
\text { and film introduction by staffs. }\end{array}$ \\
\hline $\begin{array}{l}\text { Action } \\
\text { marketing }\end{array}$ & $\begin{array}{l}\text { vision } \\
\text { hearing } \\
\text { touch }\end{array}$ & $\begin{array}{l}\text { Aboriginal traditional dance } \\
\text { Lazurite story exhibition }\end{array}$ & $\begin{array}{l}\text { Holding aboriginal dance activities or playing } \\
\text { aboriginal cultural drama can develop well } \\
\text { interaction between customers and business } \\
\text { owners. }\end{array}$ \\
\hline $\begin{array}{l}\text { Connected } \\
\text { marketing }\end{array}$ & $\begin{array}{l}\text { vision } \\
\text { hearing }\end{array}$ & $\begin{array}{l}\text { Introducing relevant } \\
\text { information by e-media } \\
\text { or web sites. }\end{array}$ & $\begin{array}{l}\text { Combining sense organs, emotions, thinking and } \\
\text { action marketing to specific population or } \\
\text { demand. In addition, allowing customers to know } \\
\text { about the cultural implications of Lazurite deeper } \\
\text { by experiential media. }\end{array}$ \\
\hline
\end{tabular}

\section{Conclusions}

This study was focused on the case study which discussed about the interior and exterior marketing strategy analysis of Ming-Show Pottery, as well as to introduce the concept of "experiential marketing" to the industry. The relevant information was obtained from domestic and foreign literatures, SWOT analysis and interviews to understand the actual operating situation deeper for the industry by field study, as well as to establish experiential marketing strategic mode by strategic experiential module and experiential media. The study results are obtained as follow:

1. The model of Experiential Strategy consists of five factors: sense, emotions, thinking, action and connection, so that the customer will interest in the product and culture if Ming-Show Pottery can stimulate those five factors.

2. The applied strategies in the future which including brand marketing, selling spots expansion, experiential marketing ways and different industrial collaboration were made via SWOT analysis as the foundational references to the industry.

3. Establishing the model of experiential marketing strategy applications can improve the competitive ability of marketing promotion for the industry, as well as to improve the interaction relations between customers, firms and products in terms of interactional marketing. 


\section{References}

[1] Huang, J.Y.: The Study of the relationship between experiential marketing, experience value and customer loyalty - An example of Starbucks. Graduate Institute of Business Administration, Soochow University (2009)

[2] Kotler, P.: Marketing Management- An Asian Perspective. Prentice Hall, Inc., Singapore (1999)

[3] Pine II, B.J., Gilmore, J.H.: Welcome to the experience economy. Harvard Business Review 76(4), 97-105 (1998)

[4] Schmitt, B.H.: Experiential Marketing: A new framework for design and communications. Designs Management Journal 10(2), 10-16 (1999)

[5] Smilansky, S.: Experiential Marketing: A Practical Guide to Interactive Brand Experiences (2009)

[6] United Nations Educational, Scientific and Cultural Organization- UNESCO (2008), http: //www. what.org.tw/unesco/

[7] Wang, W.-K.: Study Method of Education. Wunan, Taipei (2002)

[8] Guan, X.-S., et al.: The Methods of Design Research, pp. 15-31. CHWA, Taipei County (2007)

[9] Lin, Y.-J., Wang, B.-Y.: Study of discussion of IKEA's consumption situation from the view of experiential marketing. Department of Business Administration, Graduate Institute of Applied Foreign Languages, Chaoyang University of Technology (2008)

[10] Peng, Y.-C.: The Study of the Hakka cultural industry and experiential marketing - An example of Tungshih village life experience. Graduate Institute of Hakka Political Economy, National Central University (2006) 